\title{
UTILIZAÇÃO DE CATALISADORES HETEROGÊNEOS SUPORTADOS EM CARVÃO ATIVADO: SÍNTESE DE BIODIESEL DE ÓLEO DE ALGODÃO
}

\author{
Janaína Moreira de MENESES ${ }^{\mathbf{1}}$
}

\begin{abstract}
${ }^{\mathbf{1} G r a d u a d a}$ em Engenharia Química/Universidade Federal de Campina Grande (UFCG); Doutora em Engenharia Química/UFCG; Professora/Faculdade Internacional da Paraíba (FPB). E-mail: janameneses@ @otmail.com
\end{abstract}

Introdução: Diante de uma demanda crescente por energia no mundo e o aumento da poluição atmosférica causada pelo uso de combustíveis fósseis, a busca por fontes de energias renováveis vem crescendo consideravelmente. O processo utilizado pelas usinas de biodiesel emprega catalisadores homogêneos básicos, que apesar de conduzir a elevados rendimentos requer óleos altamente refinados e necessita de etapas de purificação do produto final o que vem a contribuir para um alto custo de produção do biocombustível. Objetivo: Desenvolver um catalisador heterogêneo de baixo custo que simplifique o processo de produção, fornecendo altas conversões em temperaturas brandas de reação. Metodologia: Foi preparado catalisadores metálicos suportados em carvão ativado comercial e aplicados na produção de biodiesel metílico e etílico a partir do óleo de algodão degomado e neutralizado, avaliando a conversão em ésteres. Os catalisadores foram preparados pelo método de impregnação úmida na concentração de 5\% em massa. Foram caracterizados pelas técnicas de DRX, FRX, IFTR, MEV, titulação de Boehm e análise textural. Resultados: Testes preliminares identificaram que o catalisador molibdênio ofereceu os melhores resultados na reação simultânea de esterificação/transesterificação metílica e etílica, com conversão de $43 \%$ e $40 \%$ respectivamente. Foi aplicado um planejamento fatorial $2^{3}$ para verificar o efeito das variáveis: temperatura de reação $\left(80-160{ }^{\circ} \mathrm{C}\right)$, razão molar óleo:álcool (1:6 a 1:12) e concentração de catalisador ( 1 a $3 \%$ ); sob a resposta teor de ésteres. Verificou-se que a temperatura foi a variável de maior influência e atua de forma positiva nas reações de éster/transesterificação, conduzindo a conversão de $91 \%$ em teor de ésteres. A partir de análise das superfícies de resposta, verificou-se que as condições ótimas de operação que conduzem a uma maior conversão em ésteres seriam: temperatura de $160{ }^{\circ} \mathrm{C}$, razão molar óleo:álcool de 1:13 e concentração de catalisador de 3,2 \%. Conclusões: Os resultados do ensaio de reuso mostrou que o catalisador pode ser reutilizado de forma consecutiva atingindo bons resultados, observou-se um decaimento de apenas $7 \%$ no teor de éster ao ser reutilizado no $3^{\circ}$ ciclo. $\mathrm{O}$ acompanhamento cinético demonstrou que com 5 horas de reação nas melhores condições reacionais é possível alcançar um teor de éster de 96,3\%.

Palavras-chave: catalisadores heterogêneos, reação simultânea, reuso de catalisador. 